\title{
Cometabolism degradation of lignin in sequencing batch biofilm reactors
}

\author{
Faguo Kuang, Yancheng Li, Lei He, Yongqiu Xia, Shubai Li, Jian Zhou ${ }^{\dagger}$ \\ Key Laboratory of the Gorges Reservoir's Eco-Environment, Chongqing University, 83 Shabei Road, Chongqing 400045, China
}

\begin{abstract}
Cometabolism technology was employed to degrade lignin wastewater in Sequencing Batch Biofilm Reactor. Cometabolic system (with glucose and lignin in inflow) and the control group (only lignin in inflow) were established to do a comparative study. In contrast with the control group, the average removal rates of lignin increased by $14.7 \%$ and total oarganic carbon increased by $32 \%$ in the cometabolic system with glucose as growth substrate, under the condition of $5 \mathrm{mg} / \mathrm{L} \mathrm{DO}, 0.2 \mathrm{kgCOD} /\left(\mathrm{m}^{3} \cdot \mathrm{d}\right)$ lignin and glucose $1.0 \mathrm{kgCOD} /\left(\mathrm{m}^{3} \cdot \mathrm{d}\right)$. Functional groups of lignin are degraded effectively in cometabolic system proved by fourier transform infrared spectroscopy and Gas Chromatography-Mass Spectrometer, and the degradation products were amides (mainly including acetamide, N-ethylacetamide and N, N-diethylacetamide), alcohols (mainly including glycerol and ethylene glycol) and acids. Meanwhile, results of Polymerase Chain Reaction-Denaturing Gradient Gel Electrophoresis showed great differences in microbial population richness between cometabolic system and the control group. The Margalef's richness index and Shannon-Wiener's diversity index of microorganism in cometabolic system were 3.075 and 2.61, respectively. The results showed that extra addition of glucose, with a concentration of $943 \mathrm{mg} / \mathrm{L}$, was beneficial to lignin biodegradation in cometabolic system.
\end{abstract}

Keywords: Cometabolism, Lignin, Refractory organic, SBBR

\section{Introduction}

Lignin is a network biopolymer with complex structure, and made up of guaiacylpropane, syringylpropane and p-hydroxyphenylpropane, linked by ether and carbon-carbon bonds [1, 2]. Lignin is present in the cell wall and provides the structural support and some resistance against microbial attack as well as chemical degradation [3, 4]. Papermaking wastewater and agricultural organic waste are rich in lignin, which may cause serious environment pollution if stored and discharged randomly, without any effective treatment measures [5, 6]. 50 million tons of lignin is produced by paper industry on a global scale every year [7]. Lignin and its derivatives presented in pulp-and-paper wastewater always contribute the most to its color [8].

At present, the wastewater containing lignin can be degraded effectively by biological and physicochemical methods. Lignin can be degraded by kinds of microorganisms, such as white-rotting fungi, brown rot fungus and soft-rot fungi [9, 10]. Compared with some other microbes, white-rotting fungi have been viewed with the most powerful performance in lignin degradation. It was found to secrete ligninolytic enzymes during the lignin degradation process, e.g. laccase (Lac), lignin peroxidase (Lip) and manganese peroxidase $(\mathrm{MnP})$, which all have a good performance in lignin degradation $[11,12]$. Moreover, besides the biological treatments, physicochemical technology was studied to treatment of lignin wastewater as well, such as hydrogen peroxide oxidization [13, 14], gamma-ray irradiation [15] and microwave irradiation [16]. Compared with physicochemical methods, biological treatment technology is much safer and fewer costs, which makes it a promising option for scientific research and practical application [17]. However, since lignin is of refractory organics, and sugars polymerized of lignin are natural resistance to microbial degradation. Lignin cannot be utilized as growth substrates efficiently by microbes, which results in low degradation efficiency [18]. White-rotting fungi are able to degrade lignin with acceptable efficiency, but it must be conducted under sterilizing condition, which becomes a bottleneck of engineering application of white-rotting fungi [19]. Brown rot fungus and soft-rot fungi can also degrade lignin, but they cannot degrade the benzene ring and break up its branched chain, they are not the main contributors for lignin degradation [20].
This is an Open Access article distributed under the terms of the Creative Commons Attribution Non-Commercial License (http://creativecommons.org/licenses/by-nc/3.0/) which permits unrestricted non-commercial use, distribution, and reproduction in any medium, provided the original work is properly cited.

Copyright (C) 2018 Korean Society of Environmental Engineers
Received December 4, 2017 Accepted March 6, 2018

${ }^{\dagger}$ Corresponding author

Email: zhoujiantt@126.com

Tel: +86-23-65120980 Fax: +86-23-65120980

ORCID: 0000-0002-7650-7540 
Although microorganisms cannot use refractory organics efficiently as growth substrates, they can use them as non-growth substrates, which are known as the degradation mechanism of cometabolism [21]. Cometabolism can enhance the enzymatic activity and increase the removal rate of non-growth substrates. It has been widely used in previous studies of refractory organics degradation processes, such as aromatic compounds [22], chlorinated compounds [23]. Further studies have been carried out on disposing refractory organics by cometabolism. The previous studies showed that a wide range of microbes are able to biodegrade a great variety of refractory organics by cometabolism. Nevertheless, weather lignin could be biodegraded efficiently by biological cometabolism is still unclear. Further study is required.

In this study, biological cometabolism technology has been employed to degrade lignin wastewater in Sequencing Batch Biofilm Reactor (SBBR). Cometabolic system and the control group were established to do a comparative study of the treatment efficiency and the microbial community structure changes. Fourier transform infrared spectroscopy (FTIR) and GC-MS were used to analyse the effluent characteristics. Polymerase Chain Reaction-Denaturing Gradient Gel Electrophoresis (PCR-DGGE) was used to characterise microbial community structure.

\section{Materials and Methods}

\subsection{Reactor and Operation}

The experiment was conducted in two parallel SBBRs (reactor A and reactor B). Specifically, reactor A was set as cometabolism biotreatment system with $5.0 \mathrm{mg} / \mathrm{L}$ DO and $0.2 \mathrm{kgCOD} /\left(\mathrm{m}^{3} \cdot \mathrm{d}\right)$ lignin plus $1.0 \mathrm{kgCOD} /\left(\mathrm{m}^{3} \cdot \mathrm{d}\right)$ glucose, and reactor B was set as the control group with $5.0 \mathrm{mg} / \mathrm{L} \mathrm{DO}$ and $0.2 \mathrm{kgCOD} /\left(\mathrm{m}^{3} \cdot \mathrm{d}\right)$ lignin. Both of the reactors have an effective volume of $12 \mathrm{~L}$ (with $25 \mathrm{~cm}$ in diameter and $30 \mathrm{~cm}$ in height). Combined packing materials were fixed in the reactors (with a $40 \%$ fill ratio) to enable the microorganism enrichment. Municipal sludge (10 g/L TSS) was inoculated in each reactor. The reactors were operated at an operational cycle time of $24 \mathrm{~h}$, with an operation model of four steps, (i) Inflow, wastewater was injected slowly into reactors with peristaltic pump within $0.5 \mathrm{~h}$. (ii) Aeration, clean air was aerated with air pump during operation of 22.5 h. (iii) Sedimentation, sludge was settled for $0.5 \mathrm{~h}$ after aeration stopped. (iv) Supernatant removal, supernatant of the reactors was removed with peristaltic pump within $0.5 \mathrm{~h}$. Aerators were controlled by timers to pump oxygen into the reactors. The reactors were placed in an incubator to maintain an actual water temperature of $24^{\circ} \mathrm{C} \pm 1{ }^{\circ} \mathrm{C}$. During the 80-day-operation, the concentration of chemical oxygen demand (COD), total organic carbon (TOC) and lignin in effluent was measured. Dissolved oxygen (DO, mg/L) and temperature $\left({ }^{\circ} \mathrm{C}\right)$ were monitored to maintain a stable operation condition.

\subsection{Characteristics and Analysis of Wastewater}

The main ingredient in lignin simulated wastewater was sodium lignin sulfonate, which was supplied by Aladdin. All the other chemical reagents used in the experiments were analytical and reagent grade. Inoculation microbe was obtained from municipal

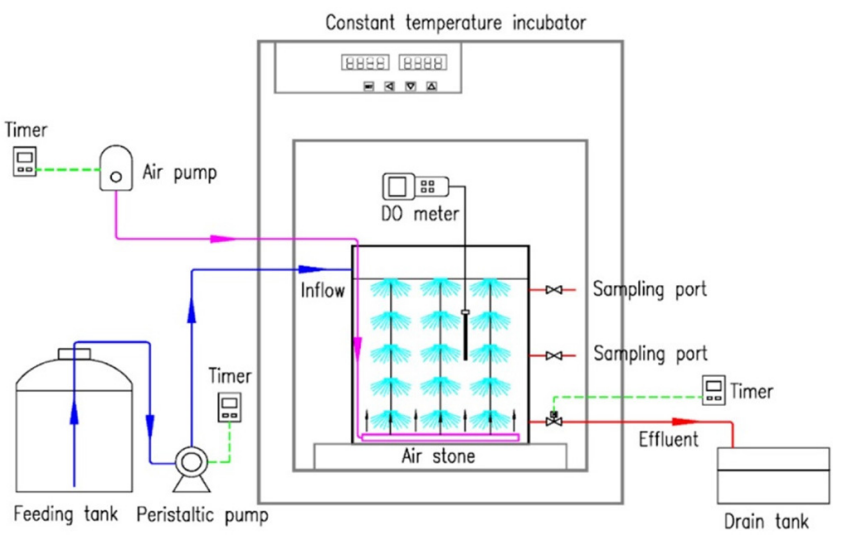

Fig. 1. Experimental equipment of SBBR.

wastewater treatment plant. Concentration of glucose and lignin were $943 \mathrm{mg} / \mathrm{L}$ and $247 \pm 5 \mathrm{mg} / \mathrm{L}$, respectively, C:N:P = 100:5:1. Microelement was added for the nutritional requirement of microorganisms and the concentration are as follows: $\mathrm{FeSO}_{4} \cdot 7 \mathrm{H}_{2} \mathrm{O}, 2.50$ $\mathrm{mg} / \mathrm{L} ; \mathrm{MgSO}_{4} \cdot 7 \mathrm{H}_{2} \mathrm{O}, 12.32 \mathrm{mg} / \mathrm{L} ; \mathrm{CaCl}_{2}, 0.55 \mathrm{mg} / \mathrm{L} ; \mathrm{MnSO}_{4}, 0.75$ $\mathrm{mg} / \mathrm{L} ; \mathrm{ZnSO}_{4} \cdot 7 \mathrm{H}_{2} \mathrm{O}, 0.43 \mathrm{mg} / \mathrm{L} ; \mathrm{COCl}_{2} \cdot 6 \mathrm{H}_{2} \mathrm{O}, 0.41 \mathrm{mg} / \mathrm{L}$ and $\mathrm{Na}_{2} \mathrm{MoO}_{4} \cdot 2 \mathrm{H}_{2} \mathrm{O}, 1.26 \mathrm{mg} / \mathrm{L}$.

The effluent COD was measured by standard methods for measurement. TOC was analysed by ultraviolet (UV)-light catalytic oxidation (Elementar Liqui TOC, Germany). A UV-visible spectrophotometer (DR5000; Hach, USA) was used to measure lignin concentration with an absorption wavelength of $280 \mathrm{~nm}$. The linear relation between lignin concentration $\mathrm{C}$ and absorbance value A was $C=158.85 \mathrm{~A}, \mathrm{R}^{2}=0.9993$ (C: $0 \mathrm{mg} / \mathrm{L}$ to $200 \mathrm{mg} / \mathrm{L}$ ).

\subsection{FTIR Analysis for Wastewater Composition}

The inflow and effluent of the cometabolism biological treatment system were collected for FTIR study. The steps are as follows: first, inflow and effluent of each $100 \mathrm{~mL}$ were frozen to solid state and powdered by vacuum freezer. Second, KBr (300 mg) was mixed in the powder (1-2 mg), and the mixture was ground by pestle and mortar in infrared light, and pressed into slice under $(5-10) \times 10^{7} \mathrm{~Pa}$. Last the spectra were collected by FTIR system (NicoletiN10, USA) equipped with diffuse reflectance accessory in a range of $400-4,000 \mathrm{~cm}^{-1}$.

\subsection{GC-MS Analysis for Wastewater Composition}

The inflow and effluent of the cometabolism biological treatment system were measured by GC-MS analyzer (Agilent 5975C/7890, USA). The inflow and effluent of each $50 \mathrm{~mL}$ were pre-treated with liquid-liquid extraction by ethyl acetate under the acidic condition $(\mathrm{pH}=2.0)$, with three repeats; afterwards, Anhydrous sodium was added into the extracted organic solvents; and condensed at 3-5 $\mathrm{mL}$ with a rotatory evaporator; next BSTFA (400 $\mathrm{uL})$ and pyridine $(100 \mathrm{uL})$ were mixed in the previous concentrates, and water bath at $60^{\circ} \mathrm{C}$ for $30 \mathrm{~min}$, the product was detected by Gas Chromatography-Mass Spectrometer (GC-MS) analyzer.

The GC-MS was conducted under the following conditions: a DB-5 $(30 \mathrm{~m} \times 0.25 \mathrm{~mm} \times 0.25 \mu \mathrm{m})$ was used; helium as carrier gas $(1.0 \mathrm{~mL} / \mathrm{min}), 250^{\circ} \mathrm{C}$ injection temperature; Temperature program 
$\left(50^{\circ} \mathrm{C}\right.$, isothermal for $7 \mathrm{~min}$; programming to $250^{\circ} \mathrm{C}$ at $10^{\circ} \mathrm{C} / \mathrm{min}$, held at $250^{\circ} \mathrm{C}$ for $5 \mathrm{~min}$ ); mass scan range was 15-650 amu; ionization, EI; electron bombardment energy was $70 \mathrm{Ev}$ and ion source temperature was $250^{\circ} \mathrm{C}$.

\subsection{Polymerase Chain Reaction-Denaturing Gradient Gel Electrophoresis (PCR-DGGE)}

A certain amount of biofilm was taken from the reactors and preserved in centrifuge. Appropriate sludge samples were placed into a $2.0 \mathrm{~mL}$ Eppendorf tube. Sample DNA was then extracted by bead beater and subjected to three freeze-thaw cycles [24]. The DNA, extracted from each sludge sample, was PCR amplified and then DGGE analysed. PCR-DGGE was adopted by Zhang et al. [25]. Margalef's richness index and Shannon-Wiener's diversity index were used to display the richness and diversity of biotreatment systems [26, 27].

Margalef's richness index was calculated as:

$$
\text { Margalef's richness index }=\frac{S-1}{\ln (N)}
$$

Shannon-Wiener's diversity index was calculated as:

$$
\text { Shannon-Wiener's diversity index }=-\sum_{i=1}^{s}\left(\frac{n_{i}}{N}\right)\left(\frac{\ln n_{i}}{N}\right)
$$

Where $S$ was number of bands, $N$ was Peak density of all bands and $n_{i}$ was Peak density of one band.

\section{Results and Discussion}

\subsection{Performance of Cometabolism Biotreatment System}

To study the influence of DO on biotreatment system, the DO concentration of both reactors were maintained in different levels of $2.0 \mathrm{mg} / \mathrm{L}, 3.5 \mathrm{mg} / \mathrm{L}$ and $5.0 \mathrm{mg} / \mathrm{L}$. Reactor A was set as cometabolism biotreatment system with $5.0 \mathrm{mg} / \mathrm{L}$ DO and 0.2 $\mathrm{kgCOD} /\left(\mathrm{m}^{3} \cdot \mathrm{d}\right)$ lignin plus $1.0 \mathrm{kgCOD} /\left(\mathrm{m}^{3} \cdot \mathrm{d}\right)$ glucose, where glucose acted as the primary substrate of cometabolic. Reactor B was set as the control group with $5.0 \mathrm{mg} / \mathrm{L}$ DO and $0.2 \mathrm{kgCOD} /\left(\mathrm{m}^{3} \cdot \mathrm{d}\right)$ lignin. As showed in Fig. 2 and Fig. 3, removal rate of lignin was relatively low in both reactors in the first $10 \mathrm{~d}$. In the next $30 \mathrm{~d}$ (reactor A) and $45 \mathrm{~d}$ (reactor B), the lignin removal rate gradually increased before climbing on a plateau in the end. As the DO concentration increased, lignin and TOC removal rate showed obvious trend of improvement. When DO concentration was $5 \mathrm{mg} / \mathrm{L}$, the removal rate of lignin and TOC reached its maximum in reactors. In reactor $\mathrm{A}$, the highest removal rate of lignin and TOC were $68.8 \%$ and $91.1 \%$, respectively. While for B, the removal rate only reached $54.1 \%$ and $58.7 \%$. At three different DO levels $(2.0 \mathrm{mg} / \mathrm{L}, 3.5 \mathrm{mg} / \mathrm{L}$ and $5.0 \mathrm{mg} / \mathrm{L})$, removal rates of lignin in reactor A were $43.8 \%, 47.4 \%$ and $68.8 \%$, which higher than reactor B by $7.6 \%, 2.7 \%$ and $14.7 \%$, respectively. On the other hand, removal rates of TOC in reactor A were $80.9 \%, 83.4 \%$ and $91.1 \%$, which higher than reactor B by $41.8 \%, 27.0 \%$ and $32.4 \%$, respectively. It is revealed that the optimal DO concentration

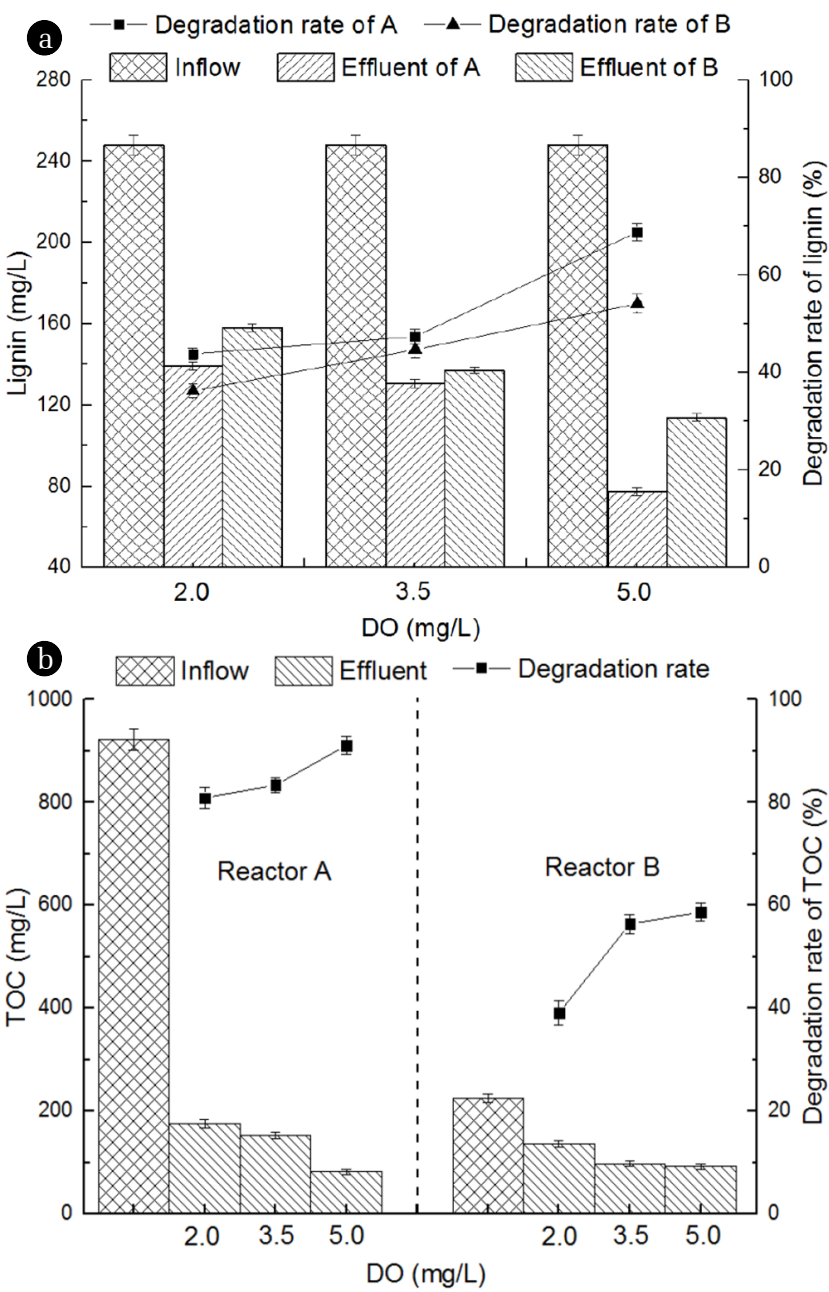

Fig. 2. Effect of dissolved oxygen on removal rate of Lignin and Total Organic Carbon (TOC) concentration in bio-treatment system (a: Lignin, b: TOC).

in this study was $5 \mathrm{mg} / \mathrm{L}$. Meanwhile, removal efficiency of cometabolic system was better than the conventional biological treatment system (the control group).

To clarify how inflow lignin load affect the removal rate of lignin and TOC, the inflow lignin load of both reactors were maintained in different levels of $0.2,0.5$ and $1.0 \mathrm{~kg} \mathrm{COD} \mathrm{kg} \mathrm{COD} /\left(\mathrm{m}^{3} \cdot \mathrm{d}\right)$, under the optimal DO concentration of $5.0 \mathrm{mg} / \mathrm{L}$. Glucose of 1.0 $\mathrm{kg} \mathrm{COD} /\left(\mathrm{m}^{3} \cdot \mathrm{d}\right)$ was added into reactor A as primary substrate of cometabolic. As showed in Fig. 4, removal rate of lignin and TOC decreased as the inflow lignin load increased in reactor $\mathrm{A}$ and B. When the inflow lignin load were maintained in $0.2,0.5$, $1.0 \mathrm{~kg} \mathrm{COD} /\left(\mathrm{m}^{3} \cdot \mathrm{d}\right)$, removal rate of lignin in reactor A were $68.8 \%$, $61.9 \%$ and $32.6 \%$, respectively, considerably higher than reactor B by $14.7 \%, 16.9 \%$ and $7.5 \%$. Removal rate of TOC in reactor A were $91.1 \%, 86.3 \%$ and $62.3 \%$, which higher than reactor B by $32.4 \%, 38.0 \%$ and $39.8 \%$, respectively.

To summarize, dosing glucose into the biotreatment system is helpful for improvement of the lignin degradation. When DO was $5 \mathrm{mg} / \mathrm{L}$, inflow lignin load was $0.2 \mathrm{~kg} \mathrm{COD} /\left(\mathrm{m}^{3} \cdot \mathrm{d}\right)$ and glucose 

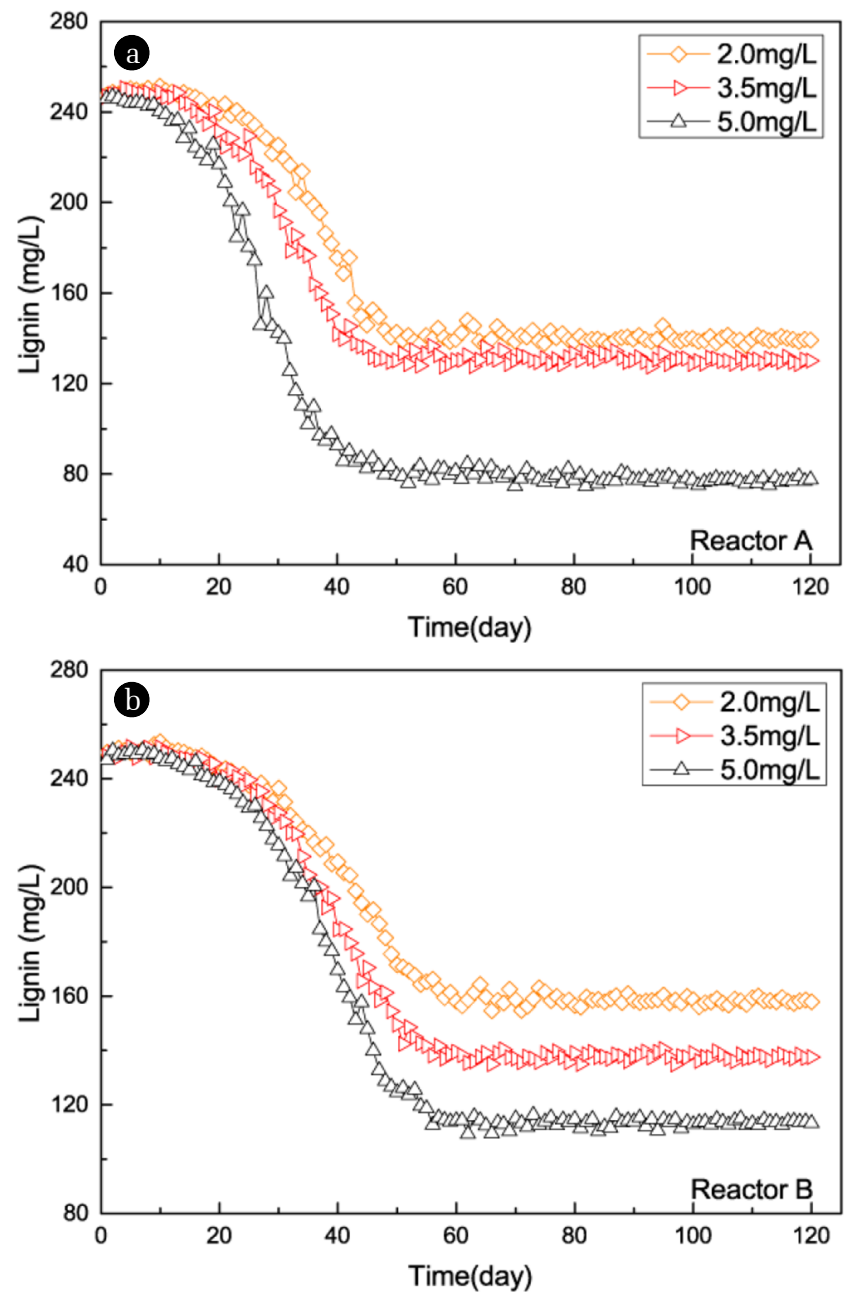

Fig. 3. Effluent lignin concentration of reactors in different DO levels during the trials.

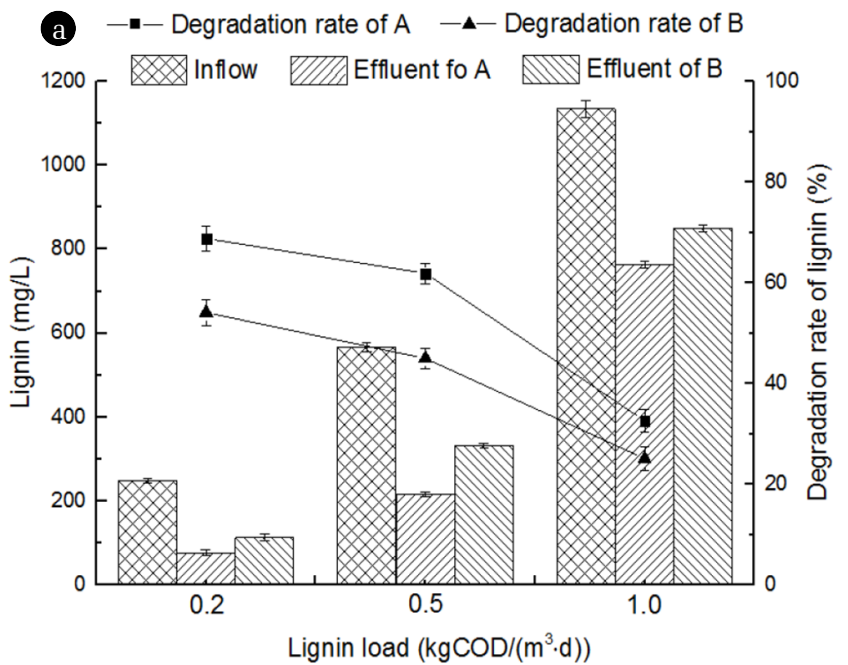

load was $1.0 \mathrm{~kg} \mathrm{COD} /\left(\mathrm{m}^{3} \cdot \mathrm{d}\right)$, the removal rate of lignin and TOC in cometabolic system were $68.8 \%$ and $91.1 \%$, respectively. The possible reason why glucose helped improve lignin degradation is that cometabolic system, with glucose as growth substrate, could be used to degrade lignin, and glucose changed the bulk ORP and built a growing environment for function bacteria [28].

\subsection{Infrared Spectrum and GC-MS Analysis of Lignin Degradation}

The inflow and effluent of reactor A was analyzed by FTIR to examine qualitative and quantitative changes in lignin degradation, while DO and lignin loading were $5.0 \mathrm{mg} / \mathrm{L}$ and $0.2 \mathrm{~kg}$ $\mathrm{COD} /\left(\mathrm{m}^{3} \cdot \mathrm{d}\right)$. The results (Fig. 5) show that a strong absorption was seen around $3,420 \mathrm{~cm}^{-1}$, which is assigned to the stretching vibration of aromatic and aliphatic - $\mathrm{OH}$ in the inflow. Two absorption at the wavelength of $2,945.42 \mathrm{~cm}^{-1}$ and $2,853.00 \mathrm{~cm}^{-1}$, which are assigned to $-\mathrm{CH}_{3}$ and $=\mathrm{CH}_{2}$, were disappeared after being treated by cometabolic system. At the wavelength of 1,593.38 $\mathrm{cm}^{-1}$ in the inflow, a strong absorption presented, assigned to the $\mathrm{C}=\mathrm{C}$ stretching of the aromatic ring. After processing by cometabolic system, the $\mathrm{C}=\mathrm{C}$ stretching was completely disappeared, while $\mathrm{O}-\mathrm{H}$ and conjugated $\mathrm{C}-\mathrm{O}$ appeared at the wavelength of $1,636.83 \mathrm{~cm}^{-1}$. According to the study of Yang Liu that wavelength of $1,456.32 \mathrm{~cm}^{-1}$ is assigned to asymmetric bending in $\mathrm{CH}_{3}$, which disappeared in the effluent [29]. Although the $\mathrm{C}-\mathrm{H}$ deformation $\left(1,419.07 \mathrm{~cm}^{-1}\right)$ still existed, the wave peak weakened obviously in the effluent. The absorption peaks of syringyl $\left(1,335 \mathrm{~cm}^{-1}\right)$, guaiacyl $\left(1,227 \mathrm{~cm}^{-1}\right)$ and $-\mathrm{O}$ - asymmetric stretching vibration completely disappeared, indicating that these function group have been degraded after treated by cometabolic system [30]. In summary, functional group of lignin was efficiently degraded in cometabolic system.

GC-MS was used to detect the effluent from cometabolic system, when DO was $5.0 \mathrm{mg} / \mathrm{L}$ and lignin loading was $0.2 \mathrm{kgCOD} /\left(\mathrm{m}^{3} \cdot \mathrm{d}\right)$. The comparison result with NIST8.0 ( $>=80 \%)$ is summarized

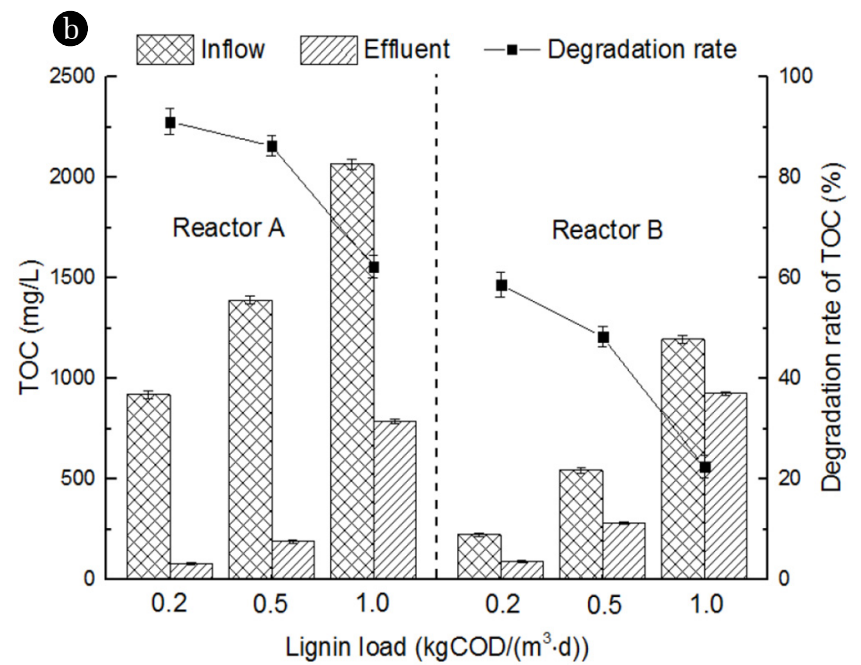

Fig. 4. Effect of lignin load on removal rate of Lignin and Total Organic Carbon (TOC) concentration in bio-treatment system (a: Lignin, b: TOC). 


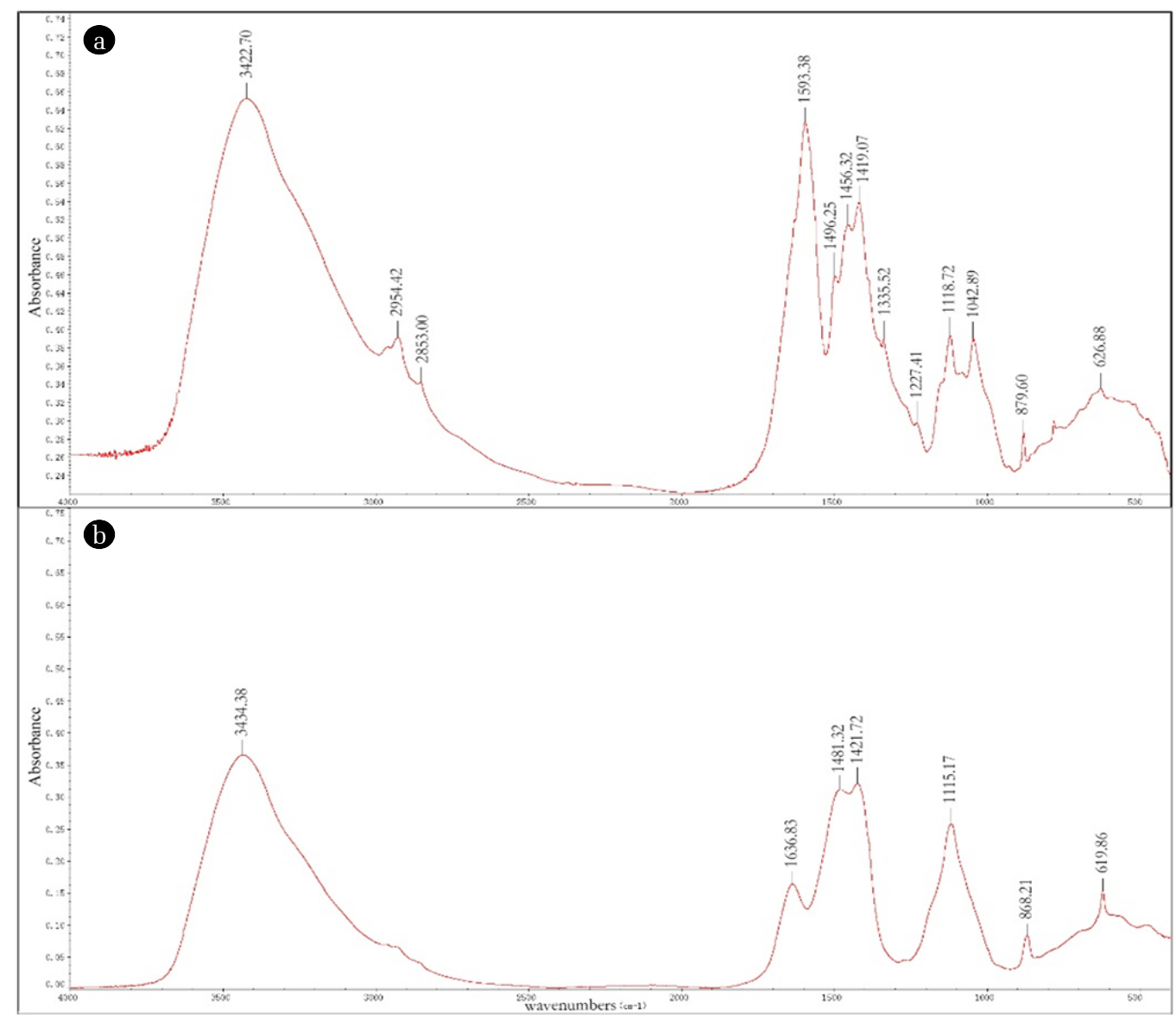

Fig. 5. The infrared spectrum of inflow and effluent (a: inflow, b: effluent).

Table 1. GC-MS Testing Result of Effluent from Cometabolic System

\begin{tabular}{|c|c|c|c|c|c|c|}
\hline Retention time/min & Molecular formula & Designation & Molecular structure & Molecular weight & Peak area & Percentage (\%) \\
\hline 11.140 & $\mathrm{C}_{4} \mathrm{H}_{9} \mathrm{NO}$ & $\begin{array}{c}\text { N-Ethyl } \\
\text { acetamide }\end{array}$ & & 87 & 4271666 & $6.311 \%$ \\
\hline 11.819 & $\mathrm{C}_{2} \mathrm{H}_{5} \mathrm{NO}$ & Acetamide & & 59 & 2166747 & $3.201 \%$ \\
\hline 13.344 & $\mathrm{C}_{2} \mathrm{H}_{6} \mathrm{O}_{2}$ & $\begin{array}{l}\text { Ethylene } \\
\text { glycol }\end{array}$ & & 62 & 26332190 & $38.905 \%$ \\
\hline 13.706 & $\mathrm{C}_{6} \mathrm{H}_{13} \mathrm{NO}$ & $\begin{array}{l}\mathrm{N}, \mathrm{N} \text {-Diethyl } \\
\text { acetamide }\end{array}$ & & 115 & 1429699 & $2.112 \%$ \\
\hline 18.334 & $\mathrm{C}_{3} \mathrm{H}_{8} \mathrm{O}_{3}$ & Glycerol & & 92 & 28944267 & $42.764 \%$ \\
\hline- & - & Acids & & - & 4539132 & $6.706 \%$ \\
\hline
\end{tabular}

in Table 1. As revealed in table 1, the main biodegradation products of lignin were alcohol, amide, and acid. Alcohol mainly contained of Ethylene glycol of $42.764 \%$ and Glycerol of $38.905 \%$, while
Amide included N-Ethyl acetamide, Acetamide and N, N-Diethyl acetamide. The proportion for each component was $6.311 \%$, $3.201 \%$ and $2.112 \%$, respectively. 


\subsection{Analysis of Lignin Degraded Microbial Groups}

Microbial richness and diversity of cometabolic system and the control group were tested by PCR-DGGE, the results is showed in Fig. 6. Lane 0 is seed sludge. Lane 1, Lane 2 and Lane 3 are sludge sample from cometabolic system (reactor A) at the condition of DO $2.0,3.0$ and $5.0 \mathrm{mg} / \mathrm{L}$, lignin loading $0.2 \mathrm{kgCOD} /\left(\mathrm{m}^{3} \cdot \mathrm{d}\right)$. Lane 4, Lane 5 and Lane 6 are sludge from the control group (reactor B) at the condition of DO 2.0, 3.0 and $5.0 \mathrm{mg} / \mathrm{L}$, lignin loading $0.2 \mathrm{~kg} \mathrm{COD} /\left(\mathrm{m}^{3} \cdot \mathrm{d}\right)$. The amount of bands of cometabolic system were 25, 26, and 30, respectively, all of which were higher than the control group. Margalef's richness index and Shannon-Wiener's diversity index were used to display the richness and diversity of biotreatment systems [26, 27], and the result is showed in Table 2. Margalef's richness index of cometabolic system is 3.08, higher than control group under the same condition with DO $5.0 \mathrm{mg} / \mathrm{L}$. Meanwhile, it is the highest among different DO levels, indicating that cometabolic system possessed the largest amount of microorganisms under the specific condition. Shannon-Wiener's diversity index of cometabolic system was 2.61, smaller than the control group under the same condition with DO $5.0 \mathrm{mg} / \mathrm{L}$, indicating that the number of microorganism species was much less in cometabolic system.

Based on the above results, a conclusion can be drawn that additional glucose can make the system much more superior in microbial richness and diversity in cometabolic system, which beneficial to lignin biodegradation.

Table 2. Richness and Diversity Index of Biotreatment System

\begin{tabular}{l|ccc|ccc}
\hline \multicolumn{1}{c|}{ Lane } & $\mathbf{1}$ & $\mathbf{2}$ & $\mathbf{3}$ & $\mathbf{4}$ & $\mathbf{5}$ & $\mathbf{6}$ \\
\hline $\begin{array}{l}\text { Margalef's richness } \\
\text { index }\end{array}$ & 2.72 & 2.63 & 3.08 & 2.30 & 2.29 & 2.55 \\
$\begin{array}{l}\text { Shannon-Wiener's } \\
\text { diversity index }\end{array}$ & 2.65 & 2.90 & 2.61 & 2.36 & 2.65 & 2.71 \\
\hline
\end{tabular}

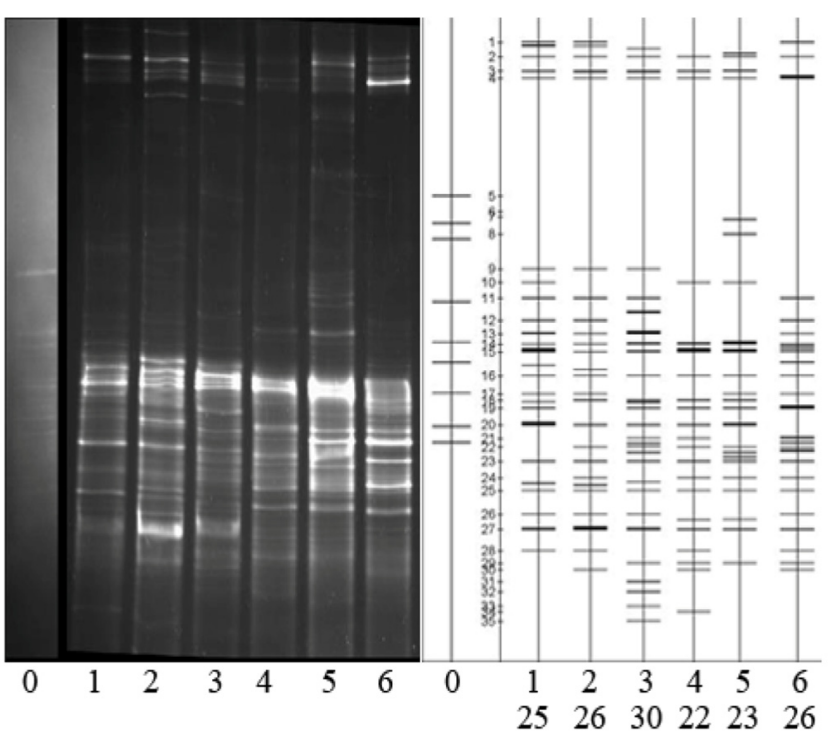

Fig. 6. DGGE fingerprinting of microbial population in two systems (lane 1-3: cometabolic system; lane 4-6: control group).

\section{Conclusions}

SBBR was used to study the lignin biodegradation by cometabolic system. Glucose was dosed into cometabolic system as primary substrate, and cometabolic system and the control group were established. A comparative study was conducted under different DO and lignin load. The results show that optimum DO concentration is $5 \mathrm{mg} / \mathrm{L}$ and optimum lignin load is $0.2 \mathrm{~kg} \mathrm{COD} /\left(\mathrm{m}^{3} \cdot \mathrm{d}\right)$. Results of FTIR and GC-MS show that functional group of lignin was efficiently degraded in cometabolic system, and the degradation products are amides, alcohols and acids. Result of PCR-DGGE show that Margalef's richness index is 3.08 and Shannon-Wiener's diversity index is 2.61. Adding glucose can make the system more superior in microbial richness and diversity in cometabolic system, and it is beneficial to microbes degrade lignin. The possible reason is that cometabolic system, with glucose as growth substrate, could be used to degrade lignin, and glucose changed the bulk ORP and built a growing environment for function bacteria.

\section{Acknowledgments}

This work was supported by The Specialized Innovation of Social and People's Livelihood in Chongqing, No. cstc2015shmszx0676.

\section{References}

1. Loow YL, Wu TY, Tan KA, et al. Recent advances in the application of inorganic salt pretreatment for transforming lignocellulosic biomass into reducing sugars. J. Agr. Food Chem. 2015;63:8349-8363.

2. Cai Y, Li G, Nie J, et al. Study of the structure and biosynthetic pathway of lignin in stone cells of pear. Sci. Hortic. 2010;125:374-379.

3. Loow Y, New EK, Yang GH, Ang LY, Foo LYW, Wu TY. Potential use of deep eutectic solvents to facilitate lignocellulosic biomass utilization and conversion. Cellulose 2017;24:3591-3618.

4. Loow Y, Wu TY, Jahim JM, Mohammad AW, Teoh WH. Typical conversion of lignocellulosic biomass into reducing sugars using dilute acid hydrolysis and alkaline pretreatment. Cellulose 2016;23:1491-1520.

5. Zhang A, Liu C, Sun R. Fractional isolation and characterization of lignin and hemicelluloses from Triploid of Populus tomentosa Carr. Ind. Crop. Prod. 2010;31:357-362.

6. Liu Y, Hu TJ, Wu ZP, et al. Study on biodegradation process of lignin by FTIR and DSC. Environ. Sci. Pollut. Res. 2014;21:14004-14013.

7. Humpert D, Ebrahimi M, Czermak P. Membrane technology for the recovery of lignin: A review. Membranes 2016;6:42.

8. Ashrafi O, Yerushalmi L, Haghighat F. Wastewater treatment in the pulp-and-paper industry: A review of treatment processes and the associated greenhouse gas emission. J. Environ. Manage. 2015;158:146-157.

9. Asina F, Brzonova I, Voeller K, et al. Biodegradation of lignin by fungi, bacteria and laccases. Bioresour. Technol. 2016;220: 
414-424.

10. Lozovaya VV, Lygin AV, Zernova OV, Li S, Widholm JM. Lignin degradation by Fusarium solani f. sp glycines. Plant Dis. 2006;90:77-82.

11. Janusz G, Kucharzyk KH, Pawlik A, Staszczak M, Paszczynski AJ. Fungal laccase, manganese peroxidase and lignin peroxidase: Gene expression and regulation. Enzyme Microb. Technol. 2013;52:1-12.

12. Zeng GM, Yu HY, Huang HL, et al. Laccase activities of a soil fungus Penicillium simplicissimum in relation to lignin degradation. World J. Microbiol. Biotechnol. 2006;22:317-324.

13. Mancera A, Fierro V, Pizzi A, et al. Physicochemical characterisation of sugar cane bagasse lignin oxidized by hydrogen peroxide. Polym. Degrad. Stabil. 2010;95:470-476.

14. Sun RC, Tomkinson J, Mao FC, Sun XF. Physicochemical characterization of lignins from rice straw by hydrogen peroxide treatment. J. Appl. Polym. Sci. 2001;79:719-732.

15. Zhang SJ, Yu HQ, Wu LX. Degradation of calcium lignosulfonate using gamma-ray irradiation. Chemosphere 2004;57:1181-1187.

16. Ouyang X, Lin Z, Deng Y, Yang D, Qiu X. Oxidative degradation of soda lignin assisted by microwave irradiation. Chinese J. Chem. Eng. 2010;18:695-702.

17. Sun Y, Qiu X, Liu Y. Chemical reactivity of alkali lignin modified with laccase. Biomass Bioenerg. 2013;55:198-204.

18. Camarero S, Martinez MJ, Martinez AT. Understanding lignin biodegradation for the improved utilization of plant biomass in modern biorefineries. Biofuel. Bioprod. Biorefin. 2014;8: 615-625.

19. D'Annibale A, Quaratino D, Federici F, Fenice M. Effect of agitation and aeration on the reduction of pollutant load of olive mill wastewater by the white-rot fungus Panus tigrinus. Biochem. Eng. J. 2006;29:243-249.

20. Kirk TK, Farrell RL. Enzymatic "combustion": The microbial degradation of lignin. Annu. Rev. Microbiol. 1987;41:465-505.
21. Nzila A. Update on the cometabolism of organic pollutants by bacteria. Environ. Pollut. 2013;178:474-482.

22. Bamforth SM, Singleton I. Bioremediation of polycyclic aromatic hydrocarbons: Current knowledge and future directions. J. Chem. Technol. Biotechnol. 2005;80:723-736.

23. Aktas O, Cecen F. Cometabolic bioregeneration of activated carbons loaded with 2-chlorophenol. Bioresour. Technol. 2009;100:4604-4610.

24. Miller DN, Bryant JE, Madsen EL, Ghiorse WC. Evaluation and optimization of DNA extraction and purification procedures for soil and sediment samples. Appl. Environ. Microbiol. 1999;65:4715-4724.

25. Zhang J, Zhou J, Han Y, Zhang X. Start-up and bacterial communities of single-stage nitrogen removal using anammox and partial nitritation (SNAP) for treatment of high strength ammonia wastewater. Bioresour. Technol. 2014;169:652-657.

26. Ding C, Chen T, Li Z, Yan J. Assessing and monitoring the ecotoxicity of pulp and paper wastewater for irrigating reed fields using the polyurethane foam unit method based on monitoring protozoal communities. Environ. Sci. Pollut. Res. 2015;22:6590-6600.

27. Miranda J, Krishnakumar G. Microalgal diversity in relation to the physicochemical parameters of some Industrial sites in Mangalore, South India. Environ. Monit. Assess. 2015;187:664.

28. Li YC, Zhou J, Gong BZ, Wang Y, He Q. Cometabolic degradation of lincomycin in a Sequencing Batch Biofilm Reactor (SBBR) and its microbial community. Bioresour. Technol. 2016;214: 589-595

29. Liu Y, Hu T, Wu Z, et al. Study on biodegradation process of lignin by FTIR and DSC. Environ. Sci. Pollut. Res. 2014;21:14004-14013.

30. Pandey KK, Pitman AJ. FTIR studies of the changes in wood chemistry following decay by brown-rot and white-rot fungi. Int. Biodeter. Biodegr. 2003;52:151-160. 